\title{
The Effect of Ash Admixture on Compost Quality and Availability of Nutrients
}

\author{
Martin Dědina ${ }^{1, * \mathbb{C}}$, Alice Jarošíková ${ }^{2}$, Petr Plíva $^{1}$ and Martin Dubský ${ }^{2}$ \\ 1 Research Institute of Agricultural Engineering, 16101 Prague, Czech Republic; petr.pliva@vuzt.cz \\ 2 Silva Tarouca Research Institute for Landscape and Ornamental Gardening, 25243 Průhonice, Czech Republic; \\ jarosikova@vukoz.cz (A.J.); dubsky@vukoz.cz (M.D.) \\ * Correspondence: martin.dedina@vuzt.cz; Tel.: +420-233-022-456
}

Citation: Dědina, M.; Jarošíková, A.; Plíva, P.; Dubský, M. The Effect of Ash Admixture on Compost Quality and Availability of Nutrients. Sustainability 2022, 14, 1640. https:// doi.org/10.3390/su14031640

Academic Editor: Antoni Sánchez

Received: 1 December 2021

Accepted: 27 January 2022

Published: 30 January 2022

Publisher's Note: MDPI stays neutral with regard to jurisdictional claims in published maps and institutional affiliations.

Copyright: (C) 2022 by the authors. Licensee MDPI, Basel, Switzerland. This article is an open access article distributed under the terms and conditions of the Creative Commons Attribution (CC BY) license (https:// creativecommons.org/licenses/by/ $4.0 /)$.

\begin{abstract}
The effect of graded doses of ash from biomass wood chips and straw admixture combustion on compost properties was investigated through a set of large-scale experiments. In a compost plant, matured organic composts were prepared from raw organic mixtures based on biodegradable waste, separated digestate, straw, and biomass ash admixture of $0,3,6$, and 9 wt. \%. Final composts, as well as individual components, were analyzed for basic physical and chemical properties, total and available nutrients, and potentially hazardous elements. Biomass ash addition increased the total nutrient content $(\mathrm{P}, \mathrm{K}, \mathrm{Mg}, \mathrm{Ca}$, and $\mathrm{S})$ in the studied composts. The highest ash addition (9 wt. \%) increased the nutrient content as follows: Ca $(2.6 \times), \mathrm{Mg}(1.6 \times), \mathrm{K}(1.5 \times), \mathrm{P}(1.2 \times)$, $\mathrm{S}(1.3 \times)$. However, the availability of some nutrients (especially $\mathrm{P}, \mathrm{K}$, and $\mathrm{Mg}$ ) for plant nutrition was reduced by the increasing amount of ash admixture. Even at the highest dosage of biomass ash addition, desirable chemical (nutrient content) and physical properties of composts (especially dry bulk density) were both obtained. The content of hazardous elements was below the legal limit values in all studied composts.
\end{abstract}

Keywords: organic compost; precision fertilizing; raw material composition; biomass ash; total nutrients; CAT soluble nutrients

\section{Introduction}

Biomass combustion plants have found increasing use as sources of renewable energy utilizing non-fossil organic material. During combustion, however, large quantities of processing waste, such as biomass ash, are produced, which requires either landfilling or further reutilization [1]. Especially nutrient-rich materials can be effectively processed into soil improvers, for example as a compost additive [2]. However, the addition of extra ingredients into composts could impair the composting process itself or negatively influence the properties of composts [3]. Because of this, the quality of ingredients, as well as the manufacturing processes, need to be carefully monitored [4]. Furthermore, all legal standards (e.g., limits of potentially hazardous elements and contaminants) should be met [5], and the final product should also be environmentally friendly without adverse effects for subsequent agricultural or horticultural application.

Organic fertilizers appear to be a sufficient substitution for commonly used mineral fertilizers [6]. Biomass ash recycling could become an efficient and common option for returning nutrients into the soil as a part of organic compost, reducing the need for further fertilization. However, biomass ashes can differ according to the source material and, therefore, their properties can vary significantly [7]. When admixed, ashes can improve the final compost quality but due to the potentially high content of contaminants, ash addition could also adversely increase salinity, and the content of metal(loid)s [8] or aromatic compounds such as polycyclic aromatic hydrocarbons (PAHs) [5]. To obtain the physical and chemical properties desirable in composts, the optimal dosage of all ingredients must be 
used. The ash admixture can significantly change the chemical composition of the compost as well as other important parameters such as $\mathrm{pH}[2,4,9]$. Several studies aiming at ash admixtures demonstrated that a high ash content in the range of 15-20 percent by weight (wt. \%) can be acceptable from a composting point of view [10-12]. On the other hand, other studies suggested that ash content of up to about $8 \mathrm{wt}$. \% represents the optimal dosage, improving the monitored properties adequately $[3,4,13,14]$. However, only a few studies monitored the availability of nutrients (mostly P) in such modified composts $[3,13,14]$, which is essential for assessing the final product for soil improvements. The main aim of this study was the evaluation of the effect of graded doses of ash from biomass combustion on organic compost properties, focusing on the content of total and available nutrients and on the content of hazardous elements. The experiment was undertaken on a large-scale basis under the real conditions of a compost plant. Ordinarily the compost plant prepared organic compost or compost with ash addition up to $3 \mathrm{wt}$. \%. Testing higher ash doses (6 and 9 wt. \%) was aimed at producing nutrient-enriched organic compost as so-called tailor-made fertilizer.

\section{Materials and Methods}

\subsection{Compost Characteristic and Experimental Set-Up}

Organic composts were prepared from raw organic mixture based on by-products of biogas production (separated digestate), biodegradable waste from greenery maintenance (weeds, grass, leaves, wood chips) from the surrounding area of the composting plant, and straw. The compost mixtures were composed of naturally moist raw materials and prepared on a bulk-density basis. The total weight of raw organic material mixtures ranged from 140 to $170 \mathrm{Mg}$. The weight fraction of individual components was in the range of 55-65 wt. \% (separated digestate), 25-35 wt. \% (biodegradable waste), and 5-10 wt. \% (straw). In addition to organic components, ash from biomass (wood chips and straw admixture in a ratio of approximately 4:1) combustion, originating from the municipal heating plant, was admixed. In this heating plant, biomass used as a fuel consisted of wood chips obtained from pieces of trunks or branches, with a wood content of more than $75 \%$ and leaf litter content of less than $25 \%$. The dimensions of wood chips should be $30 \times 30 \times 70 \mathrm{~mm}$ (and rarely, wood pieces with a length of $100 \mathrm{~mm}$ ), a maximum moisture content of $50 \%$, a bulk density of $170-300 \mathrm{~kg} / \mathrm{m}$, a calorific value of 9-15 MJ/kg, and an ash content of $2 \%$ maximally. The straw used originated from wheat only. The doses of the ash were recalculated into $10 \%$ dry matter content. Raw organic mixtures with ash dry matter contents of $0,3,6$, and 9 wt. \% resulted in final matured composts (O, A3, A6, A9).

The composition of the raw organic mixture was prepared in order to meet the expected, predeterminate qualities for the final compost in terms of nutrient content and physical and chemical properties before the composting piles were formed. Four replicates of each experimental compost were prepared in a compost plant with year-round operation belonging to a local agricultural holding in the Czech Republic in the period between 2015 and 2018. The technology for controlled composting was applied. Piles $(90 \times 3 \times 1.8 \mathrm{~m})$ of the compost mixture were stocked in a covered, water-secure area with controlled continuous aeration, and the composting process of each sample lasted for 7 weeks in the same part of each year (June-July). Within this time, the compost piles were turned three times by a compost turner to homogenize the composted material.

\subsection{Analytical Methods}

The composts, as well as their individual components, were analyzed for basic physical and chemical properties according to the European Standards. Both the pH [15] and electric conductivity (EC) [16] were measured in deionized water leachates ( $v / v$ ratio 1:5). Laboratory-compacted bulk density was determined using a one litre cylinder [17].

The total contents of element and nutrient concentrations ( $\mathrm{Al}, \mathrm{As}, \mathrm{Be}, \mathrm{Ca}, \mathrm{Co}, \mathrm{Cr}, \mathrm{Cu}$, $\mathrm{Fe}, \mathrm{K}, \mathrm{Mg}, \mathrm{Mn}, \mathrm{Mo}, \mathrm{Na}, \mathrm{Ni}, \mathrm{P}, \mathrm{S}, \mathrm{V}, \mathrm{Zn}$ ) were measured by inductively coupled plasma optical emission spectrometry (ICP-OES; PE Optima 5300DV) after total digestion by a 
mixture of $\mathrm{HNO}_{3}-\mathrm{H}_{2} \mathrm{O}_{2}-\mathrm{HF}$ in Teflon vessels in a closed microwave digestion system (CEM; Mars 5). Total nitrogen and carbon concentrations were analyzed in powdered specimens by combustion in a CN Determinator (LECO; TruSpec) and then the C/N ratio was calculated. A total of $12 \mathrm{PAHs}$ were determined by liquid chromatography with a fluorescence detector (HPLC/FLD; EN 16181; [18]): naphthalene, phenanthrene, anthracene, fluoranthene, pyrene, benzo(a)anthracene, chrysene, benzo(b)fluoranthene, benzo(k)fluoranthene, benzo(a)pyrene, benzo(g,h,i)perylene, and indeno(1,2,3-c,d)pyrene. Available nutrient contents $(\mathrm{Cu}, \mathrm{Fe}, \mathrm{K}, \mathrm{Mg}, \mathrm{Mn}, \mathrm{N}, \mathrm{P}, \mathrm{Zn})$ were determined using the CAT leaching agent ( $\mathrm{v} / \mathrm{v}$ ratio $1: 5 ;$ [19]). The content of available nutrients was converted to $\mathrm{g} / \mathrm{kg}$ of dry matter and compared with the total nutrient content. For each analytical method, the quality of the results was checked by measuring certified standard reference materials.

The results were statistically evaluated by analysis of variance and Duncan's test (Unistat 4.53 Software, Unistat Ltd, London, UK).

Limit values of hazardous elements in compost vary within European countries [20]. Every compost should be therefore considered according to the individual country's law. In our study, we compared the measured values with the limit values required by the current Czech standard of the Ministry of Agriculture (Decree No. 474/2000 Coll.). According to the classification suggested by [20], the Czech standard limits meet the criteria for high quality compost.

\section{Results and Discussion}

The basic physical and chemical properties of composts and individual components are displayed in Table 1. Electric conductivity of composts ranged between $2.37-3.60 \mathrm{mS} / \mathrm{cm}$. Given the properties of biomass ash, $\mathrm{pH}$ in composts increased with the ash addition from 8.2 (O) to 9.1 (A9). The bulk density and dry matter content increased as well.

Table 1. Basic physical and chemical properties of composts and individual components.

\begin{tabular}{|c|c|c|c|c|c|}
\hline & WBD & DBD & DM & $\mathrm{pH}$ & EC \\
\hline & $g / L$ & $\mathrm{~g} / \mathrm{L}$ & $\%$ & & $\mathrm{mS} / \mathrm{cm}$ \\
\hline $\mathrm{O}$ & $394 \pm 49^{c}$ & $180 \pm 40^{d}$ & $45.9 \pm 9.0^{b}$ & $8.2^{c}$ & $2.37^{\mathrm{c}}$ \\
\hline A3 & $527 \pm 49^{b}$ & $238 \pm 27^{c}$ & $45.3 \pm 11.5^{b}$ & $8.6^{b}$ & $3.37^{\mathrm{a}}$ \\
\hline A6 & $526 \pm 49^{b}$ & $257 \pm 40^{b}$ & $48.8 \pm 3.2^{b}$ & $9.0^{\mathrm{a}}$ & $3.23^{a b}$ \\
\hline A9 & $595 \pm 49^{a}$ & $292 \pm 30^{a}$ & $49.0 \pm 3.2^{b}$ & $9.1^{\mathrm{a}}$ & $3.60^{\mathrm{a}}$ \\
\hline $\mathrm{BW}$ & $570 \pm 76$ & $197 \pm 16$ & $34.6 \pm 2.1$ & $6.6 \pm 0.5$ & 2.85 \\
\hline STR & $187 \pm 32$ & $96.0 \pm 6.0$ & $51.3 \pm 6.8$ & $7.4 \pm 0.2$ & 0.37 \\
\hline SEP & $544 \pm 61$ & $108 \pm 2.6$ & $19.8 \pm 0.1$ & $8.6 \pm 0.1$ & 1.51 \\
\hline ASH & $634 \pm 46$ & $436 \pm 0$ & $68.7 \pm 0.4$ & $10.9 \pm 0.4$ & 8.47 \\
\hline
\end{tabular}

When possible, the results are presented as X \pm SDY (X-mean value; SD—standard deviation; Y-statistical evaluation. The values are followed by relevant case letters $(a, b, c)$. The means with same superscripts within a column are not significantly different at $p<0.05$. according to Duncan's test. WBD-wet bulk density DBD—dry bulk density; DM-dry matter; EC — electrical conductivity; BW—biodegradable waste; STR—straw; $\mathrm{SEP}$ - separated digestate; ASH_-biomass ash.

The content of nutrients in composts and individual components is presented in Table 2. The $\mathrm{C} / \mathrm{N}$ ratio of composts ranged between 10.3-12.1. The nutrient composition of the final organic compost (O) was: $32.40 \mathrm{~g} / \mathrm{kg} \mathrm{K}, 24.70 \mathrm{~g} / \mathrm{kg} \mathrm{Ca}, 12.40 \mathrm{~g} / \mathrm{kg} \mathrm{P}, 0.94 \mathrm{~g} / \mathrm{kg} \mathrm{Mg}$, and $0.63 \mathrm{~g} / \mathrm{kg}$ S. The ash was generally rich in all macronutrients. The total nutrient content in the dry matter of the ash was $105.00 \mathrm{~g} / \mathrm{kg} \mathrm{Ca}, 63.60 \mathrm{~g} / \mathrm{kg} \mathrm{K}, 16.20 \mathrm{~g} / \mathrm{kg} \mathrm{Mg}, 10.50 \mathrm{~g} / \mathrm{kg} \mathrm{P}$, and $7.63 \mathrm{~g} / \mathrm{kg} \mathrm{S}$. The sodium content was $2.56 \mathrm{~g} / \mathrm{kg}$ in the organic compost $(\mathrm{O})$ and $3.32 \mathrm{~g} / \mathrm{kg}$ in the ash. In the final compost with the highest ash content (A9), the added ash increased the content of the total nutrients as follows: $\mathrm{Ca}(2.6 \times), \mathrm{Mg}(1.6 \times), \mathrm{K}(1.5 \times)$, $\mathrm{P}(1.2 \times), \mathrm{S}(1.3 \times)$, and $\mathrm{Na}(1.2 \times)$. Conversely, the ash addition reduced the content of total $\mathrm{C}(1.3 \times)$ and $\mathrm{N}(1.4 \times)$. 
Table 2. Content of nutrients and sodium in composts and individual components.

\begin{tabular}{|c|c|c|c|c|c|c|c|c|c|}
\hline & $\mathrm{C}$ & $\mathbf{N}$ & $\mathrm{C} / \mathrm{N}$ & $\mathbf{P}$ & $\mathbf{K}$ & $\mathrm{Mg}$ & $\mathrm{Ca}$ & $S$ & $\mathrm{Na}$ \\
\hline & $\%$ & $\%$ & & \multicolumn{6}{|c|}{$\mathrm{g} / \mathrm{kg}$} \\
\hline $\mathrm{O}$ & $31.3 \pm 2.5^{b}$ & $3.06 \pm 0.13^{a}$ & $10.3 \pm 0.7^{\mathrm{a}}$ & $12.4 \pm 1.4^{\mathrm{c}}$ & $32.4 \pm 3.4^{\mathrm{c}}$ & $9.40 \pm 0.4^{c}$ & $24.7 \pm 3.5^{\mathrm{d}}$ & $6.32 \pm 0.32^{c}$ & $3.32 \pm 0.88^{b}$ \\
\hline A3 & $30.9 \pm 2.2^{c}$ & $2.59 \pm 0.20^{b}$ & $11.9 \pm 1.0^{\mathrm{a}}$ & $12.1 \pm 2.2^{\mathrm{c}}$ & $36.7 \pm 6.1^{\mathrm{c}}$ & $10.3 \pm 1.3^{c}$ & $42.4 \pm 2.6^{c}$ & $8.43 \pm 1.06^{\mathrm{a}}$ & $3.68 \pm 0.72^{a b}$ \\
\hline A6 & $27.9 \pm 1.8^{\mathrm{d}}$ & $2.31 \pm 0.17^{c}$ & $12.1 \pm 1.0^{\mathrm{a}}$ & $13.4 \pm 0.6^{\mathrm{b}}$ & $43.8 \pm 2.5^{b}$ & $12.2 \pm 0.3^{b}$ & $48.5 \pm 2.9^{b}$ & $7.75 \pm 0.95^{b}$ & $3.82 \pm 0.16^{a}$ \\
\hline A9 & $23.9 \pm 0.5^{\mathrm{e}}$ & $2.15 \pm 0.05^{\mathrm{d}}$ & $11.1 \pm 0.9^{\mathrm{a}}$ & $14.3 \pm 0.3^{a}$ & $48.0 \pm 1.0^{\mathrm{a}}$ & $14.6 \pm 0.7^{\mathrm{a}}$ & $64.4 \pm 5.7^{\mathrm{a}}$ & $8.36 \pm 0.29^{a}$ & $3.98 \pm 0.30^{\mathrm{a}}$ \\
\hline BW & $41.3 \pm 0.3$ & $2.16 \pm 0.13$ & $19.6 \pm 1.2$ & $4.10 \pm 0.6$ & $29.3 \pm 2.9$ & $2.86 \pm 0.2$ & $10.8 \pm 2.5$ & $3.44 \pm 0.3$ & $0.65 \pm 0.1$ \\
\hline STR & $44.8 \pm 0.3$ & $0.46 \pm 0.14$ & $109 \pm 36.3$ & $1.40 \pm 0.1$ & $9.80 \pm 0.8$ & $0.65 \pm 0.3$ & $2.29 \pm 0.7$ & $1.06 \pm 0.2$ & $0.18 \pm 0.1$ \\
\hline SEP & $43.5 \pm 0.3$ & $1.45 \pm 0.08$ & $30.2 \pm 1.7$ & $8.00 \pm 0.3$ & $15.0 \pm 0.6$ & $4.88 \pm 0.1$ & $9.82 \pm 0.3$ & $4.72 \pm 0.4$ & $1.03 \pm 0.2$ \\
\hline ASH & $22.9 \pm 2.2$ & $0.16 \pm 0.04$ & $73.1 \pm 13.6$ & $10.5 \pm 0.2$ & $63.6 \pm 0.7$ & $16.2 \pm 3.1$ & $105 \pm 24.4$ & $7.63 \pm 1.9$ & $2.56 \pm 0.8$ \\
\hline
\end{tabular}

When possible, the results are presented as $\mathrm{X} \pm \mathrm{SDY}(\mathrm{X}$-mean value; SD—standard deviation; $\mathrm{Y}$-statistical evaluation. The values are followed by relevant case letters $(a, b, c)$. The means with same superscripts within a column are not significantly different at $\mathrm{p}<0.05$. according to Duncan's test. O-organic compost; A3, A6, A9-organic compost with a biomass ash admixture of 3, 6, and $9 \mathrm{wt} \%$; BW—biodegradable waste; STR—straw; $\mathrm{SEP} —$ separated digestate; ASH—biomass ash.

Besides the dilution of organic compost by the ash admixture, the lower $\mathrm{C}$ content could be explained by enhanced mineralization (i.e., decomposition of organic compounds in the compost) [12], whereas the decrease in $\mathrm{N}$ could be caused by volatilization. The availability of nutrients in the organic compost $(\mathrm{O})$ was determined at $9 \% \mathrm{~N}, 25 \% \mathrm{P}$, $92 \% \mathrm{~K}, 23 \% \mathrm{Mg}, 0.3 \% \mathrm{Fe}, 3.5 \% \mathrm{Mn}, 4,2 \% \mathrm{Zn}$, and $0.4 \% \mathrm{Cu}$. Figure 1 shows available nutrient contents (N, P, K, Mg, Fe) in composts. Decreasing availability of nutrients in composts with a graded dose of ash was clearly observed. Compared with organic compost $(\mathrm{O})$, the availability of nutrients in the compost with the highest ash admixture (A9) decreased as follows: P by $20 \%$, K by $29 \%$, Mg by $16 \%, \mathrm{~N}$ by $1 \%$, Fe by $0.2 \%$, Mn by $2 \%$, and $\mathrm{Zn}$ by $3 \%$. Conversely, $\mathrm{Cu}$ availability increased with ash admixture, from $0.4(\mathrm{O})$ to $1.6 \%$ (A9). Lower concentrations of total nitrogen $(\mathrm{N})$ in composts had almost no effect on the availability of $\mathrm{N}$. Available fractions of $\mathrm{P}, \mathrm{K}, \mathrm{Mg}$, and Fe decreased with the addition of the ash component, although the total concentrations of these elements were detected as increased in the investigated composts. Supposedly, $\mathrm{P}, \mathrm{K}, \mathrm{Mg}$, and Fe were still captured in the non-available sources. The presence of high concentrations of $\mathrm{Ca}, \mathrm{Mg}, \mathrm{Fe}$, and /or $\mathrm{K}$, as well as alkaline $\mathrm{pH}$ values, could affect the availability of nutrients by the formation of species with low solubility. For instance, increasing amounts of $\mathrm{Ca}$ can stimulate the formation of highly stable apatite-group phases [21]. The formation of low-soluble Ca-P aggregates may lead to the sink of a large amount of $\mathrm{P}$, making it scarce for plants [22]. However, the availability of nutrients would probably be changed after the application of compost into the soil, where lower $\mathrm{pH}$ and different moisture conditions typically occur [6]. Moreover, soil biota also plays a major role in the solubilization of insoluble nutrients, increasing their availability to plants [23].

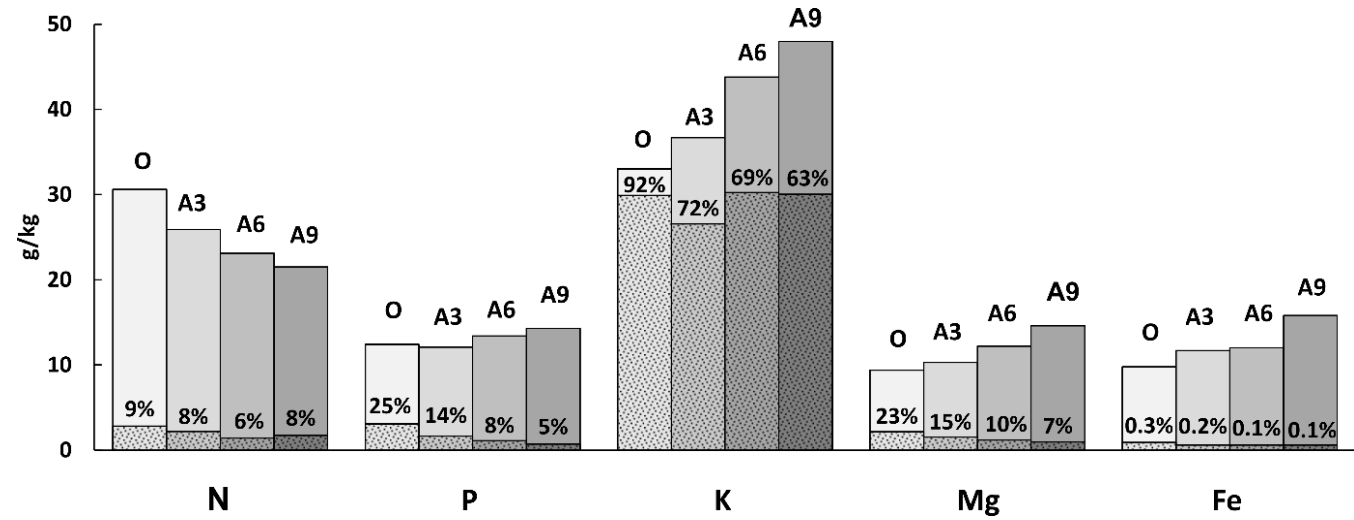

Figure 1. The percentage of the available nutrient contents $(\mathrm{N}, \mathrm{P}, \mathrm{K}, \mathrm{Mg}$, and $\mathrm{Fe}$ ) compared with the total concentrations in composts. O-organic compost; A3, A6, A9-organic composts with a biomass ash admixture of 3,6 , and 9 wt. \%, respectively. 
The contents of risk elements and micronutrients in composts and individual components are presented in Table 3. In the case of biomass ash and composts containing ash (A3, A6, A9), all risk elements were below the limit of legal standards. Nevertheless, cadmium was just below the limit both in the ash and A9-compost. Therefore, an admixture of ash higher than 9 wt. \% would probably not meet the legal criteria. In all composts and individual components including ash, each of the twelve measured PAHs values was determined to be below $0.5 \mathrm{mg} / \mathrm{kg}$, which was significantly below the limit of $20 \mathrm{mg} / \mathrm{kg}$.

Table 3. Content of risk elements and micronutrients in composts and individual components compared with the limit values.

\begin{tabular}{|c|c|c|c|c|c|c|c|c|c|c|c|c|c|c|c|}
\hline & Al & $\mathrm{Fe}$ & Mn & $\mathrm{Zn}$ & $\mathrm{Cu}$ & Mo & $\mathrm{Cd}$ & $\mathrm{Pb}$ & $\mathrm{Hg}$ & As & $\mathrm{Cr}$ & $\mathbf{N i}$ & Be & Co & V \\
\hline & & $\mathrm{g} / \mathrm{kg}$ & & \multicolumn{12}{|c|}{$\mathrm{mg} / \mathrm{kg}$} \\
\hline $\mathrm{O}$ & $\begin{array}{c}14.5 \\
\pm \underset{b}{4} .9\end{array}$ & $\begin{array}{c}9.80 \\
\pm \underset{c}{3} .0\end{array}$ & $\begin{array}{c}0.47 \\
\pm \\
0.06 \\
d\end{array}$ & $\begin{array}{c}185 \\
\pm \underset{c}{c} 8.5\end{array}$ & $\begin{array}{c}39.9 \\
\pm \underset{c}{ } 3.7\end{array}$ & $\begin{array}{c}3.48 \\
\pm \\
0.96^{\mathrm{a}}\end{array}$ & $\begin{array}{c}0.37 \\
\pm \\
0.06 \\
d\end{array}$ & $\begin{array}{c}7.30 \\
\pm \underset{\mathrm{a}}{ } 6.7\end{array}$ & $\begin{array}{c}0.04 \\
\pm \\
0.01 \\
b\end{array}$ & $\begin{array}{c}2.48 \\
\pm \\
0.75 \\
b\end{array}$ & $\begin{array}{c}19.1 \\
\pm \underset{c}{ } 5.3\end{array}$ & $\begin{array}{c}10.8 \\
\pm \underset{c}{ } 3.7\end{array}$ & $\begin{array}{c}0.66 \\
\pm \\
0.22\end{array}$ & $\begin{array}{c}4.51 \\
\pm \\
1.56^{\mathrm{c}}\end{array}$ & $\begin{array}{c}35.0 \\
\pm \\
10.8^{\mathrm{b}}\end{array}$ \\
\hline A3 & $\begin{array}{c}15.0 \\
\pm_{b} 1.3\end{array}$ & $\begin{array}{c}11.7 \\
\pm_{b c} 0.5\end{array}$ & $\begin{array}{c}0.97 \\
\pm \\
0.11^{\mathrm{c}}\end{array}$ & $\begin{array}{c}293 \\
\pm \stackrel{ \pm}{b} \\
13.5^{b}\end{array}$ & $\begin{array}{c}64.4 \\
\pm \underset{b}{4} .7\end{array}$ & $\begin{array}{c}4.35 \\
\pm \\
0.13^{\mathrm{a}}\end{array}$ & $\begin{array}{c}1.10 \\
\pm \\
0.17^{\mathrm{c}}\end{array}$ & $\begin{array}{c}9.30 \\
\pm \underset{a}{0}\end{array}$ & $\begin{array}{c}0.05 \\
\pm \\
0.01 \\
\mathrm{~b}\end{array}$ & $\begin{array}{c}2.77 \\
\pm \\
0.25 \\
\mathrm{ab}\end{array}$ & $\begin{array}{c}28.4 \\
\pm 1.1 \\
\mathrm{ab}\end{array}$ & $\begin{array}{c}16.5 \\
\pm 0.9 \\
\mathrm{~b}\end{array}$ & $\begin{array}{c}0.73 \\
\pm \\
0.07^{\mathrm{a}}\end{array}$ & $\begin{array}{c}5.97 \\
\pm \\
0.32 \\
\mathrm{~b}\end{array}$ & $\begin{array}{c}40.6 \\
\pm_{b} 1.5\end{array}$ \\
\hline A6 & $\begin{array}{c}17.4 \\
\pm \underset{\mathrm{ab}}{1.4}\end{array}$ & $\begin{array}{c}12.0 \\
\pm 0.4 \\
\mathrm{~b}\end{array}$ & $\begin{array}{c}1.19 \\
\pm \\
0.14 \\
b\end{array}$ & $\begin{array}{c}303 \\
\pm \\
17.8\end{array}$ & $\begin{array}{c}63.3 \\
\pm 1.9 \\
\mathrm{~b}\end{array}$ & $\begin{array}{c}4.30 \\
\pm \\
0.79^{\mathrm{a}}\end{array}$ & $\begin{array}{c}1.54 \\
\pm \\
0.26 \\
b\end{array}$ & $\begin{array}{c}13.7 \\
\pm \underset{\mathrm{a}}{4} .6\end{array}$ & $\begin{array}{c}0.06 \\
\pm \\
0.01^{\mathrm{a}}\end{array}$ & $\begin{array}{c}3.18 \\
\pm \\
0.22^{\mathrm{a}}\end{array}$ & $\begin{array}{c}26.3 \\
\pm \underset{b}{2.8}\end{array}$ & $\begin{array}{c}16.7 \\
\pm 1.7 \\
\mathrm{~b}\end{array}$ & $\begin{array}{c}0.84 \\
\pm \\
0.08\end{array}$ & $\begin{array}{c}6.63 \\
\pm \\
0.39 \\
\mathrm{~b}\end{array}$ & $\begin{array}{c}40.5 \\
\pm \underset{b}{ } 1.8\end{array}$ \\
\hline A9 & $\begin{array}{c}19.4 \\
\pm \underset{\mathrm{a}}{0.9}\end{array}$ & $\begin{array}{c}15.8 \\
\pm \underset{\mathrm{a}}{1.2}\end{array}$ & $\begin{array}{c}1.47 \\
\pm \\
0.11^{\mathrm{a}}\end{array}$ & $\begin{array}{c}356 \\
\pm \\
13.3^{a}\end{array}$ & $\begin{array}{c}73.2 \\
\pm \underset{\mathrm{a}}{1.4}\end{array}$ & $\begin{array}{c}5.09 \\
\pm \\
0.98^{\mathrm{a}}\end{array}$ & $\begin{array}{c}1.96 \\
\pm \\
0.06^{\mathrm{a}}\end{array}$ & $\begin{array}{c}14.5 \\
\pm 2.4 \\
\mathrm{a}\end{array}$ & $\begin{array}{c}0.05 \\
\pm \\
0.001 \\
\mathrm{ab}\end{array}$ & $\begin{array}{c}3.21 \\
\pm \\
0.23^{\mathrm{a}}\end{array}$ & $\begin{array}{c}33.6 \\
\pm \underset{\mathrm{a}}{4.2}\end{array}$ & $\begin{array}{c}22.7 \\
\pm 3.9 \\
\mathrm{a}\end{array}$ & $\begin{array}{c}0.85 \\
\pm \\
0.13^{\mathrm{a}}\end{array}$ & $\begin{array}{c}9.66 \\
\pm \\
1.48^{\mathrm{a}}\end{array}$ & $\begin{array}{c}53.2 \\
\pm 2.2 \\
\mathrm{a}\end{array}$ \\
\hline $\mathrm{COM}_{*} \mathrm{lim}$ & - & - & - & 600 & 150 & 20 & 2 & 100 & 0.5 & 20 & 50 & 50 & - & - & - \\
\hline BW & $\begin{array}{c}0.92 \\
\pm \\
0.82\end{array}$ & $\begin{array}{c}0.66 \\
\pm \\
0.68\end{array}$ & $\begin{array}{c}0.04 \\
\pm \\
0.01\end{array}$ & $\begin{array}{c}16.3 \\
\pm 3.2\end{array}$ & $\begin{array}{c}3.60 \\
\pm 1.2\end{array}$ & $\begin{array}{c}1.35 \\
\pm \\
0.38\end{array}$ & $\begin{array}{c}0.04 \\
\pm \\
0.01\end{array}$ & $\begin{array}{c}0.42 \\
\pm \\
0.25\end{array}$ & $\begin{array}{c}0.01 \\
\pm \\
0.002 \\
\mathrm{a}\end{array}$ & $\begin{array}{c}0.16 \\
\pm \\
0.13\end{array}$ & $\begin{array}{c}6.20 \\
\pm 3.4\end{array}$ & $\begin{array}{c}4.50 \\
\pm 1.9\end{array}$ & $\begin{array}{c}0.03 \\
\pm \\
0.02\end{array}$ & $\begin{array}{c}0.39 \\
\pm \\
0.24\end{array}$ & $\begin{array}{c}2.69 \\
\pm \\
1.45\end{array}$ \\
\hline STR & $\begin{array}{c}2.80 \\
\pm \\
0.42\end{array}$ & $\begin{array}{c}2.05 \\
\pm \\
0.48\end{array}$ & $\begin{array}{c}0.17 \\
\pm \\
0.02\end{array}$ & $\begin{array}{c}52.4 \\
\pm 7.0\end{array}$ & $\begin{array}{c}11.4 \\
\pm 2.0\end{array}$ & $\begin{array}{c}3.29 \\
\pm \\
0.54\end{array}$ & $\begin{array}{l}0.13 \\
0.04\end{array}$ & $\begin{array}{c}2.00 \\
\pm \\
0.54\end{array}$ & $\begin{array}{c}0.02 \\
\pm \\
0.004\end{array}$ & $\begin{array}{c}0.75 \\
\pm \\
0.39\end{array}$ & $\begin{array}{c}17.6 \\
\pm 4.0\end{array}$ & $\begin{array}{c}12.5 \\
\pm 2.0\end{array}$ & $\begin{array}{c}0.12 \\
\pm \\
0.03\end{array}$ & $\begin{array}{c}1.27 \\
\pm \\
0.28\end{array}$ & $\begin{array}{l}7.18 \\
\pm 2.0\end{array}$ \\
\hline SEP & $\begin{array}{c}1.08 \\
\pm \\
0.11\end{array}$ & $\begin{array}{c}1.64 \\
\pm \\
0.44\end{array}$ & $\begin{array}{c}0.18 \\
\pm \\
0.01\end{array}$ & $\begin{array}{c}119 \\
\pm 4.5\end{array}$ & $\begin{array}{c}21.3 \\
\pm 4.5\end{array}$ & $\begin{array}{c}3.98 \\
\pm \\
1.86\end{array}$ & $\begin{array}{c}0.17 \\
\pm \\
0.02\end{array}$ & $\begin{array}{c}0.75 \\
\pm \\
0.08\end{array}$ & $\begin{array}{c}0.01 \\
\pm \\
0.01\end{array}$ & $\begin{array}{c}0.41 \\
\pm \\
0.06\end{array}$ & $\begin{array}{l}8.30 \\
\pm 4.0\end{array}$ & $\begin{array}{c}10.2 \\
\pm 4.0\end{array}$ & $\begin{array}{c}0.03 \\
\pm \\
0.01\end{array}$ & $\begin{array}{c}1.37 \\
\pm \\
1.01\end{array}$ & $\begin{array}{c}3.00 \\
\pm \\
0.47\end{array}$ \\
\hline $\mathrm{ASH}$ & $\begin{array}{c}23.0 \\
\pm 6.8\end{array}$ & $\begin{array}{c}19.3 \\
\pm 3.4\end{array}$ & $\begin{array}{c}3.51 \\
\pm \\
0.83\end{array}$ & $\begin{array}{c}430 \\
\pm 98 \\
\end{array}$ & $\begin{array}{c}76.2 \\
\pm \\
13.2\end{array}$ & $\begin{array}{c}1.99 \\
\pm \\
0.41\end{array}$ & $\begin{array}{c}4.46 \\
\pm \\
0.83\end{array}$ & $\begin{array}{c}17.5 \\
\pm 5.0\end{array}$ & $\begin{array}{c}0.14 \\
\pm \\
0.03\end{array}$ & $\begin{array}{c}3.22 \\
\pm \\
0.71\end{array}$ & $\begin{array}{c}28.8 \\
\pm 5.5\end{array}$ & $\begin{array}{c}18.7 \\
\pm 3.9\end{array}$ & $\begin{array}{c}1.02 \\
\pm \\
0.56\end{array}$ & $\begin{array}{c}10.0 \\
\pm 2.2\end{array}$ & $\begin{array}{c}49.4 \\
\pm \\
17.1\end{array}$ \\
\hline $\mathrm{BA}_{*}$ & - & - & - & - & - & - & 5 & 50 & 0.5 & 20 & 50 & - & - & - & - \\
\hline
\end{tabular}

* Limit values required by the current Czech standard of the Ministry of Agriculture. When possible, the results are presented as $X \pm S D Y(X-$ mean value; $S D$-standard deviation; $Y$-statistical evaluation. The values are followed by relevant case letters $(a, b, c)$. The means with same superscripts within a column are not significantly different at $p<0.05$. according to Duncan's test. $\mathrm{O}$-organic compost; A3, A6, A9-organic compost with a biomass ash admixture of 3, 6, and 9 wt. \%; $\mathrm{COM}_{\mathrm{lim}}$ - limit values for composts; BW-biodegradable waste; $\mathrm{STR}$ —straw; SEP—separated digestate; $\mathrm{ASH}$ —biomass ash; $\mathrm{BA}_{\text {lim }}$-limit values for biomass ash.

\section{Conclusions}

The aforementioned results bring clear evidence that waste materials, such as byproducts derived from combustion processes, biogas production, and greenery maintenance, can be successfully used for organic compost production while respecting all legal criteria. In our case, the biomass ash addition of $9 \mathrm{wt}$. \% was the optimal dosage which represented a balance between the desirable physical and chemical properties, total nutrient content, and risk elements and compounds. The availability of some nutrients in the compost can be restricted by the addition of extra ash admixture, leading to changes in the content of available nutrients and $\mathrm{pH}$ value. Nevertheless, nutrient availability can be altered after the eventual application of compost to the soil where different $\mathrm{pH}$ conditions and water regimes typically occur. The main limiting factor of ash addition in keeping the 
final compost below the limit values is the content of $\mathrm{Cd}$. With a higher dosage of ash (over 9 wt. \%), there is already a risk that the Cd legal limits for composts would be exceeded.

To conclude, the amount of ash admixed into the compost can affect its main chemical properties as well as its final quality. When adding an extra admixture into composts, the technological procedures should be chosen correctly, and the quality of the ingredients should be also monitored carefully in order to obtain the most efficient soil improver. Particular emphasis should be placed on the availability of elements and nutrients as well as on the parameters of the soil into which the final compost will be eventually admixed.

Author Contributions: Conceptualization, M.D. (Martin Dědina) and M.D. (Martin Dubský); methodology, P.P. and M.D. (Martin Dubský); writing—original draft preparation, A.J. and Martin Dubský.; project administration, P.P.; funding acquisition, P.P. and M.D. (Martin Dědina). All authors have read and agreed to the published version of the manuscript.

Funding: This research was funded by the institutional support of the Silva Tarouca Research Institute for Landscape and Ornamental Gardening (VUKOZ-IP-00027073), by the institutional support for long-term development of the Research Institute of Agricultural Engineering p.r.i. (RO0618) and by the Ministry of Agriculture of the Czech Republic grant number QK1920177.

Institutional Review Board Statement: Not applicable.

Informed Consent Statement: Not applicable.

Data Availability Statement: The data presented in this study are available on request from the corresponding author, and have not been placed in a public repository.

Conflicts of Interest: The authors declare no conflict of interest.

\section{References}

1. Singh, A.K.; Masto, R.E.; Hazra, B.; Esterle, J.; Singh, P.K. Ash from Coal and Biomass Combustion, 1st ed.; Springer: Cham, Switzerland, 2020.

2. Asquer, C.; Cappai, G.; Carucci, A.; De Gioannis, G.; Muntoni, A.; Piredda, M.; Spiga, D. Biomass ash characterisation for reuse as additive in composting process. Biomass Bioenergy 2019, 123, 186-194. [CrossRef]

3. Asquer, C.; Cappai, G.; De Gioannis, G.; Muntoni, A.; Piredda, M.; Spiga, D. Biomass ash reutilisation as an additive in the composting process of organic fraction of municipal solid waste. Waste Manag. 2017, 69, 127-135. [CrossRef] [PubMed]

4. Kurola, J.M.; Arnold, M.; Kontro, M.H.; Talves, M.; Romantschuk, M. Wood ash for application in municipal biowaste composting. Bioresour. Technol. 2011, 102, 5214-5220. [CrossRef] [PubMed]

5. Silva, F.C.; Cruz, N.C.; Tarelho, L.A.C.; Rodrigues, S.M. Use of biomass ash-based materials as soil fertilisers: Critical review of the existing regulatory framework. J. Clean. Prod. 2019, 214, 112-124. [CrossRef]

6. Hanč, A.; Tlustoš, P.; Száková, J.; Balík, J. The influence of organic fertilizers application on phosphorus and potassium bioavailability. Plant Soil Environ. 2008, 54, 247-254. [CrossRef]

7. Zając, G.; Szyszlak-Bargłowicz, J.; Gołębiowski, W.; Szczepanik, M. Chemical Characteristics of Biomass Ashes. Energies 2018, 11, 2885. [CrossRef]

8. Fernández-Delgado Juárez, M.; Prähauser, B.; Walter, A.; Insam, H.; Franke-Whittle, I.H. Co-composting of biowaste and wood ash, influence on a microbially driven-process. Waste Manag. 2015, 46, 155-164. [CrossRef] [PubMed]

9. Ricardo, O.-O.E.; Fernando, M.-R.L.; Patricia, T.-L. Evaluation of the Addition of Wood Ash to Control the $\mathrm{pH}$ of Substrates in Municipal Biowaste Composting. Ing. Investig. Y Tecnol. 2014, 15, 469-478. [CrossRef]

10. Fernández-Delgado Juárez, M.; Gómez-Brandón, M.; Insam, H. Merging two waste streams, wood ash and biowaste, results in improved composting process and end products. Sci. Total Environ. 2015, 511, 91-100. [CrossRef] [PubMed]

11. Koivula, N.; Räikkönen, T.; Urpilainen, S.; Ranta, J.; Hänninen, K. Ash in composting of source-separated catering waste. Bioresour. Technol. 2004, 93, 291-299. [CrossRef] [PubMed]

12. Kuba, T.; Tschöll, A.; Partl, C.; Meyer, K.; Insam, H. Wood ash admixture to organic wastes improves compost and its performance. Agric. Ecosyst. Environ. 2008, 127, 43-49. [CrossRef]

13. Bougnom, B.P.; Mair, J.; Etoa, F.X.; Insam, H. Composts with wood ash addition: A risk or a chance for ameliorating acid tropical soils? Geoderma 2009, 153, 402-407. [CrossRef]

14. Bougnom, B.P.; Knapp, B.A.; Elhottová, D.; Koubová, A.; Etoa, F.X.; Insam, H. Designer compost with biomass ashes for ameliorating acid tropical soils: Effects on the soil microbiota. Appl. Soil Ecol. 2010, 45, 319-324. [CrossRef]

15. EN 13037; Soil Improvers and Growing Media-Determination of pH. European Committee for Standardization: Brussels, Belgium, 2011.

16. EN 13038; Soil Improvers and Growing Media—Determination of Electrical Conductivity. European Committee for Standardization: Brussels, Belgium, 2012. 
17. EN 13040; Soil Improvers and Growing Media—Sample Preparation for Chemical and Physical Tests, Determination of Dry Matter Content, Moisture Content and Laboratory Compacted Bulk Density. European Committee for Standardization: Brussels, Belgium, 2007.

18. EN 16181; Soil, Treated Biowaste and Sludge-Determination of Polycyclic Aromatic Hydrocarbons (PAH) by Gas Chromatography (GC) and High-Performance Liquid Chromatography (HPLC). European Committee for Standardization: Brussels, Belgium, 2007.

19. EN 13651; Soil Improvers and Growing Media-Extraction of Calcium Chloride/DTPA (CAT) Soluble Nutrients. European Committee for Standardization: Brussels, Belgium, 2001.

20. Genevini, P.L.; Adani, F.; Borio, D.; Tambone, F. Heavy Metal Content in Selected European Commercial Composts. Compost. Sci. Util. 2013, 5, 31-39. [CrossRef]

21. Vanden Nest, T.; Amery, F.; Fryda, L.; Boogaerts, C.; Bilbao, J.; Vandecasteele, B. Renewable P sources: P use efficiency of digestate, processed animal manure, compost, biochar and struvite. Sci. Total Environ. 2021, 750, 141699. [CrossRef] [PubMed]

22. Vandecasteele, B.; Sinicco, T.; D’Hose, T.; Vanden Nest, T.; Mondini, C. Biochar amendment before or after composting affects compost quality and N losses, but not P plant uptake. J. Environ. Manag. 2016, 168, 200-209. [CrossRef] [PubMed]

23. Hanc, A.; Chadimova, Z. Nutrient recovery from apple pomace waste by vermicomposting technology. Bioresour. Technol. 2014, 168, 240-244. [CrossRef] [PubMed] 